
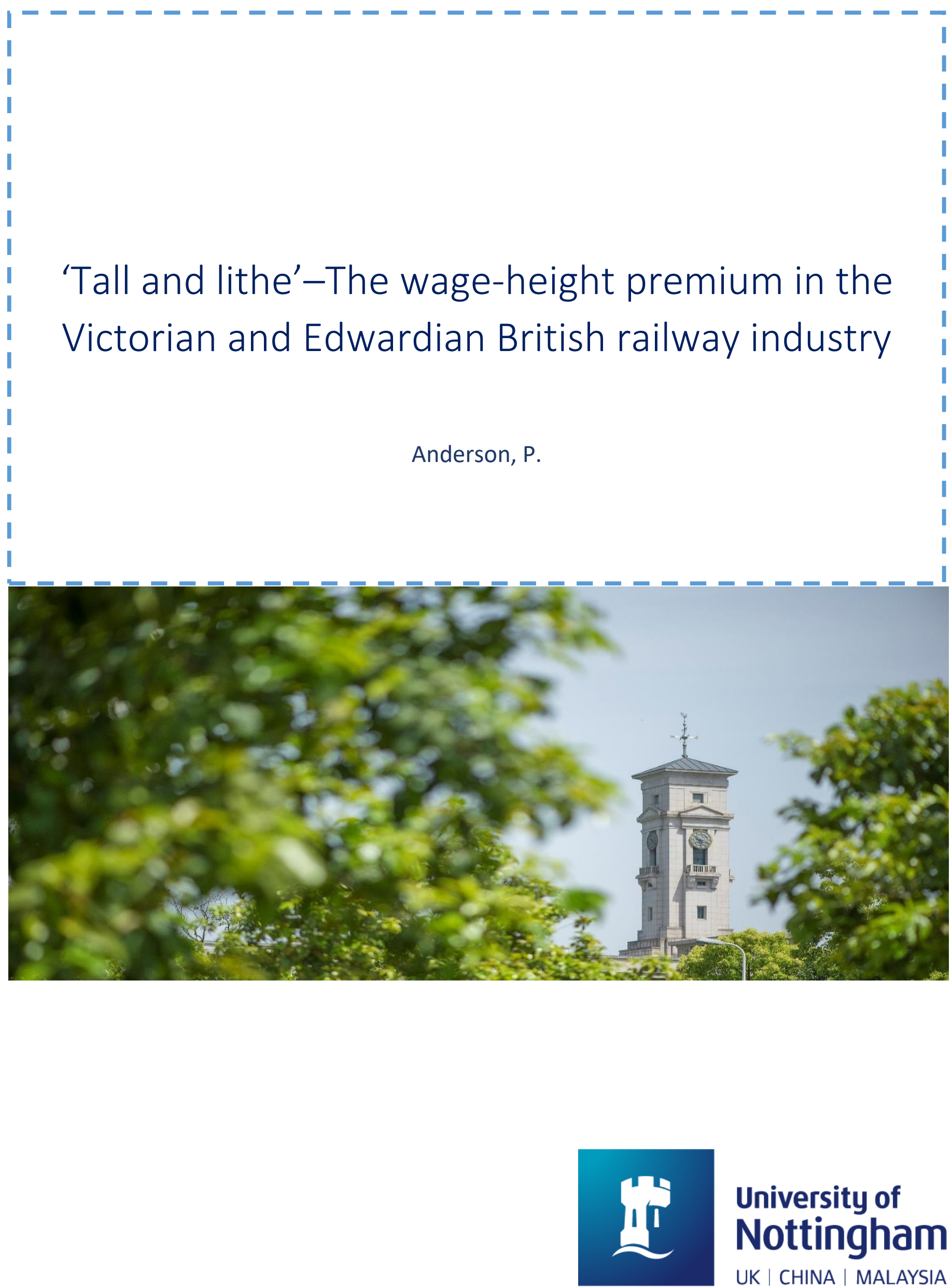
University of Nottingham Ningbo China, 199 Taikang East Road, Ningbo, 315100, Zhejiang, China.

First published 2017

This work is made available under the terms of the Creative Commons Attribution 4.0 International License:

http://creativecommons.org/licenses/by/4.0

The work is licenced to the University of Nottingham Ningbo China under the Global University Publication Licence:

https://www.nottingham.edu.cn/en/library/documents/researchsupport/global-university-publications-licence-2.0.pdf 


\title{
'Tall and lithe'-The wage-height premium in the Victorian and Edwardian British railway industry
}

\author{
Peter Anderson \\ University of Nottingham Ningbo China, China
}

\section{a R T i c e i n f o}

\section{Keywords:}

British railway industry

Railwaymen

Internal labour markets

Wage-height premium

Anthropometric history

Cognitive ability

Non-cognitive ability

Heightism

\begin{abstract}
a b s T R a c T
Studies in anthropometrics continue to find a wage-height premium in modern economies despite most productivity not contingent on physical strength. These authors argue that height is a proxy for cognitive and non-cognitive abilities, which earns the positive return. In this paper, I collected data on over 2,200 English and Welsh railwaymen from staff ledgers to test if the same relationship held during the Victorian and Edwardian period. Using an OLS model, it is found that a wage-height premium existed. Applying the same model to different subgroups of railwaymen, it was found that the premium only accrued to taller men working in skilled grades that required a higher cognitive and non-cognitive skill to strength ratio. No such premium existed in the physically taxing entry-level railway grades. A probit regression finds that taller Great Western signalmen working in Wales did not have a lower probability of receiving a fine upon committing an infraction; a finding that contradicts heightism as an explanation of the wage-height premium. I conclude that taller railwaymen benefited because height indirectly measured their cognitive and non-cognitive abilities, not their strength.
\end{abstract}

(C) 2017 Elsevier Inc. All rights reserved.

\section{Introduction}

That taller people earn more, controlling for a number of factors, is a common finding in labour market studies testing for this relationship. This study analyses the surviving data on railwaymen's height from the operating and traffic staffs of three prominent Victorian and Edwardian British railway companies, the London and North-Western, the Great Western, and the London and SouthWestern. It will test whether taller railwaymen earned more and, if so, why.

Studies have shown that height positively impacts the wages of urban-dwelling Brazilian men and women (Thomas and Strauss, 1997) and the daily wage rate of Ethiopian agricultural workers (Croppenstedt and Muller, 200o). Historically, a positive relationship existed between physical stature and socioeconomic status in eighteenth-century Germany (Komlos, 1990) as well as the height of American slaves and their value (Margo and Steckel, 1982).

The finding on American slaves implies that the wage-height premium existed in non-modern labour markets because greater height signified an individual's greater strength. Floud et al. (1990) hypothesised that in Victorian and Edwardian Britain greater height might imply a worker's superior physical capabilities or his or her better resistance to diseases that reduced work effort.

Studies of modern labour markets seek to explain the wage-height premium in market contexts where productivity is not dependent on physical prowess. The conclusions generally hold that taller people received a higher wage because height is a proxy for an individual's cognitive and or non-cognitive skills, not strength. Palloni (2006) illustrates the relationship of how better childhood nutrition leads to taller heights and better cognitive and non-cognitive achievements in adulthood, positively linking these three outcomes. Bozzoli et al. (2009) and two studies by Case and Paxon (2008a) find that better cognitive abilities, not strength, explain

E-mail address: peter.anderson@nottingham.edu.cn 


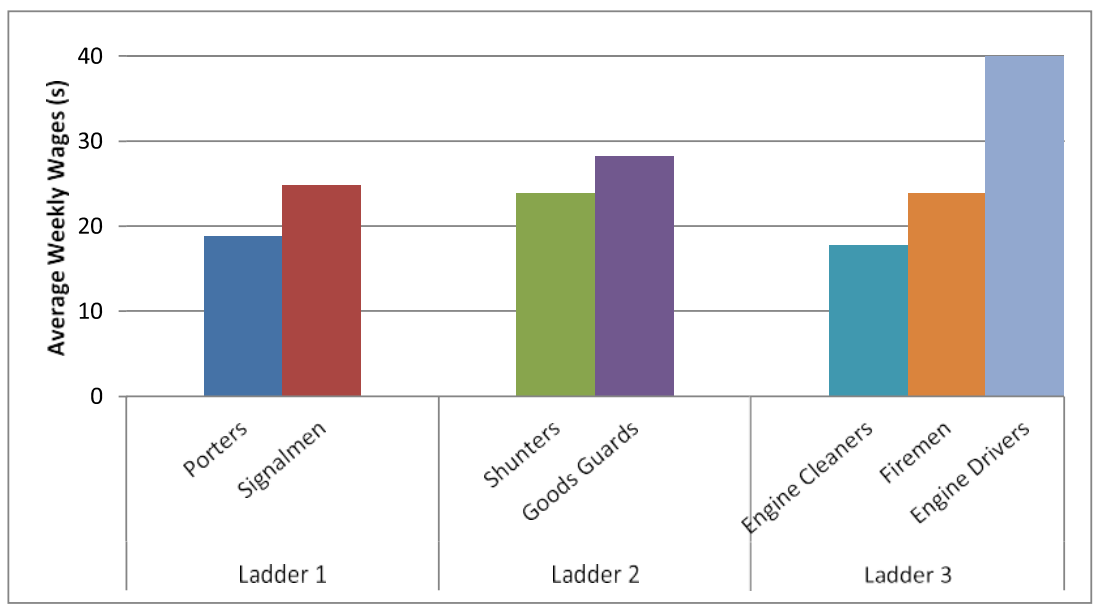

Fig. 1. Selected British railway job ladders.

Source: see text.

Note: entry-level grades are on the left of each ladder.

the wage-height premium. The latter's (Case and Paxon, 2008b) analysis of modern British workers found that the introduction of an independent variable for educational attainment caused the height premium to fall by half for men and two thirds for women.

Lundborg et al. (2014) studied Swedish men fulfilling mandatory military service and concluded that 'there is not one story' to explain the wage-height premium, citing cognitive ability, muscle strength at the time of enlistment, and discrimination against short people as contributing factors. Schick and Steckel's (2015) analysis of Britain's National Childhood Development Study found that good childhood nutrition leads to taller children that have greater cognitive and non-cognitive ability, which together positively impact earnings. It is then worth noting the strong empirical link between general cognitive ability and job performance, a link that one researcher says is 'not logically possible' to question (Schmidt, 2002).

This paper uses a newly-collected data set of over 2200 railwaymen to see how these findings relate to the pre-First World War British railway industry. Using an OLS regression, it finds that a wage-height premium existed in the railway industry. Running the same regression for four subsets of railwaymen shows that only the skilled grades received a statistically significant wage-height premium. Skilled jobs necessitated greater cognitive to physical ability relative to the unskilled grades from which these men were promoted, indicating that the wage-height premium was due to height representing a man's greater cognitive and or non-cognitive abilities, not his physical strength. Furthermore, station masters were statistically taller than other railwaymen in the data set while height did not lower a man's probability of receiving a monetary punishment for committing an infraction. This latter finding rejects heightism as an explanation for the wage-height premium.

\section{Institutional setting}

The importance with which contemporaries viewed the Victorian and Edwardian British railway industry was partially due to its sheer size (Wardley, 1991), putting them amongst the 'exceptional firms' of their time (Gospel, 1992). Circa 1907, railway companies comprised 10 of the 15 largest employers in the United Kingdom (Wardley, 1999) and the industry had an average annual employment of 675,711 individuals from 1895-1913 ( $P P$, Accident Reports). The London and North-Western and Great Western employed a combined total of more than 145,000 waged and salaried workers in the week ending 11 February 1911 (PP 1913, (116)).

To manage their large and dispersed workforces, British railway companies began to formalise their informal internal labour markets in the late nineteenth century. Firms using an internal labour market characteristically fill job openings through internal promotions, provide limited opportunities for entry into employment for non-firm workers, and generally protect employees from external competition (Doeringer and Piore, 1985).

The railway industry recruited men from the agricultural and working classes ( $P P$ 1911, [Cd. 5927]) and family networks (NA, RAIL 1025/18) and divided railway work into a number of positions called grades. Screening of railway entrants differed by company. The Great Eastern required prospective porters to pass a medical test and provide character testimonials (RAIL 1025/10) while another man, who described himself as a 'tall (6 feet) and lithe...hefty young man', recounted that a chief inspector looked over a group of applicants, then chose him and three others to work as goods porters (Kenney, 1939).

From the entry-level grades, railwaymen could potentially obtain promotion to a grade higher up the internal job ladder. Kingsford writes of 'well defined...channels of advancement' (1970, p. 138) before 1870, but his own evidence belies this as porters, an entrylevel grade, received advancement to a variety of grades such as guards, policemen, and even salaried clerks. Subsequent scholarship agrees that railway companies did not formalise their internal labour markets until the 1870s or later (Howlett, 2000, 2004; Savage, 1998), but by 1907 the Board of Trade could report a 'normal system of promotion as between certain grades on the railways' ( $P P$ 1912-13, [Cd. 6053]). Fig. 1 visualises the three separate job ladders mentioned by the Board of Trade with average weekly wages, in shillings, taken from the same 1907 study (PP 1912-13, [Cd. 6053]). 
In practice, these promotional paths were not always codified (PP 1912-13, [Cd. 6014]) and railwaymen could enter higher grades from more than just one lower grade. However, Howlett's study of the Great Eastern corroborates the first two ladders (2004) in Fig. 1, Joby also confirms Ladder 1 (1984), and Savage shows Ladder 3 existed in the Great Western (1998).

Railwaymen had means for advancement within a given grade, not just through vertical promotion. In 1907, the North British Railway listed 26 and 18 different pay levels for porters and signalmen, respectively. Wages in part depended on tenure (NRS, $\mathrm{BR} / \mathrm{LAS} / \mathrm{S}$ /49), a common practice in the industry for all grades as growth in a man's company-specific skills made him more valuable to his employer and vice versa. Grades also had different pay scales at different stations, which companies periodically changed (NA, RAIL 410/1804). Great Western goods guards, a grade the Board of Trade classified with brakesmen, ${ }^{1}$ could earn up to $30 \mathrm{~s}$ a week, but the 'exceptionally smart and able' could earn $32 \mathrm{~s}$ (NA, RAIL 1025/21). Working in a larger city and the increase in work and responsibility that it entailed also meant higher pay (PP 1912-13, [Cd. 6053]). Great Eastern goods guards in London had an averageweekly wage rate $1.67 \mathrm{~s}$ higher than guards stationed in the country while London signalman earned $5.25 \mathrm{~s}$ more a week than country signalman (NA, RAIL 1025/10). Such regional discrepancies also applied to first-year porters and shunters ( $P P$ 1911, [Cd. 5927]; $P P$ 1912-13, [Cd. 6014]).

A man's tenure in a specific grade or station varied by company. Promotion was fast in times of growth, but discontent grew amongst British railwaymen in the early twentieth century as expansion of the industry retarded. ${ }^{2}$ This meant fewer opportunities for advancement in an industry with long-tenured workers; younger railwaymen's prospects became one of 'waiting on dead men's shoes' (NA, Rail 1025/18, p. 96). After a threatened strike in 1907, a strike in August 1911, and two Conciliation and Arbitration Schemes, the British government allowed rate increases to cover companies' increased labour bills (Alderman, 1971), which included improvements in wages and benefits such as bonuses and overtime pay.

\subsection{Recruitment of the tall and healthy}

The turn-of-the-century British railway industry demanded physical and mental fitness. In the early years of the railway industry, the supply of labour outstripped demand and railway companies independently set similar minimum height requirements, although the threshold declined over time (Kingsford, 1970). An internal paper from the Great Western said that the company appointed 'only robust likely-looking young men' as engine cleaners (NA, RAIL 264/10) and a Superintendent said 'We seek as far as we can to take intelligent men on to start with' (NA, RAIL 1025/21). The North Eastern set a minimum of 65 inches for cleaners seeking promotion to the fireman grade (NA, RAIL 527/1258) and a Great Western memo states that the company made promotion contingent not only on height, but also the quality of an employee's teeth (NA, RAIL 264/11).

Railway companies may have also recognised the association between height and other non-strength related factors, such as health or cognitive ability. One former railway clerk recounted that his company measured his height when he began work (Simmons, 1974) even though clericalwork did not require physical exertion.

\subsection{Operating and traffic railway grades}

Railway operating and traffic staffs, the focus of this study, were dominated by the four grades in Ladder 1 and 2 in Fig. 1. Excluding permanent way men and locomotive men such as drivers and firemen, these four grades comprised $72 \%$ of adult railwaymen in 1907 . This was a male-dominated industry at its most integrated, employing just 126 women and girls in the same year ( $P P$ 1912-13, [Cd. 6053]).

Performance of duties in the entry-level grades porter or shunter required greater physical exertion relative to the respective grade to which hopefuls could receive promotion. Goods and passenger porters were in charge of loading and unloading goods and passenger trains, respectively. The moving of luggage and goods necessitated a minimum level of physical strength and although companies employed lads in these grades, adults had a decided advantage in work requiring heavy lifting or greater reach. Passengerporters dealt directly with passengers and it is possible that passengers who preferred taller men more generously tipped tall porters. Literacy was also necessary. In its early days of operation, the Great Western required literate porters that were 'generally intelligent'(Kingsford, 1970, p. 9) and this demand for literacy in an expanding industry would have in part offset the effect of a growing supply of literate workers (Schofield, 1973) on railwaymen's wages. Only when expansion of the railway industry slowed at the turn of the century would one expect a lower return to literacy and intelligence.

The signalman grade required a greater degree of cognitive ability relative to muscle. A Great Eastern official stated that his company sought to promote the 'more efficient and intelligent' porters to signalmen (NA, RAIL 1025/10). Attainment of this grade generally required completion of schooling to learn the tasks and finally the confirmation of an inspector after a period of working under a qualified signalman (NA, BR/LAS/S/105). Companies sometimes employed lads in this grade, but the work meant cleaning signal cabins and learning the adult signalman's tasks rather than performing them (Westwater, 1979). Similarities exist for assistant signalmen, an apprentice-like entry-level job adults sometimes filled.

Adult signalmen needed the intelligence to learn and memorise the differing points and signals controlled from their box, the codes of different trains as they related to these points, and the literacy and numeracy skills to keep records of passing trains. Signalman work also required the strength to pull the levers operating the points and a taller man with greater reach might have had some advantage.

\footnotetext{
1 This paper also classifies goods guards and brakesmen together.

${ }^{2}$ Industry-wide annual growth in passenger + goods train miles averaged 1.4\% from 1900-12. In the preceding 20 years, it averaged $3.2 \%$ ( $P P 1881-1913$, Returns). TFP growth also slipped for most major companies during this period (Crafts et al., 2011).
} 
Nevertheless, signalmen's cognitive and non-cognitive abilities determined their import to their employer because errors in signalling could lead to train accidents. As the narrator in Charles Dickens's short story 'Signal'man' wrote, 'exactness and watchfulness were what was required of (a signalman), and of actual work - manual labour - he had next to none' (1866).

In regards to Ladder 2 from Fig. 1, shunting duty revolved around coupling and uncoupling the rolling stock and marshalling trains. Shunters needed basic literacy and numeracy to correctly order wagons and put them in the right sidings, duties a Great Western superintendent deemed 'not a difficult job' (NA, RAIL 1025/21, p. 684). To aid their work, shunters often used a shunting pole, a 5 to 7 foot long ash pole used to couple or uncouple wagons. The poles increased the safety of shunting operations, but they were too large for the boys working in goods yards and only the stronger adult railwaymen could handle them (Kenney, 1913). Smaller people seemingly had no advantage in this grade, as there were no lad shunters in the industry.

Promotion to goods guard (brakesman) did not end shunting work, but the skills needed in this grade far surpassed those of shunters. The Great Western only advanced shunters that passed an oral exam and showed an 'aptitude for the higher work' (NA, RAIL 1025/21, p. 688). Goods guards, not engine drivers, were in charge of train safety. This included helping test the train breaks prior to departure and putting in place safety precautions if the train had to stop on the line before completing its journey. During a train journey, goods guards needed to apply the train's brake over differing gradients to keep the couplings tight. They also needed to be literate in order to remain abreast of changing work rules and to make certain that the correct wagons were deposited at the correct stations along the route.

Errors or dereliction of duty on the part of either signalmen or goods guards could lead to train accidents, which was costly to companies in both lives and capital. Railway companies thus had an incentive to promote intelligent and vigilant men to these positions, not necessarily the brawniest, in order to minimise the risk of costly accidents. Two other factors also illustrate that these grades relied more on non-physical skills for their completion.

The first is on-the-job injury, which is one way to quantify the physical onerosity of a grade. Entry-level railway work entailed greater danger, due to its physical demands, relative to the next rung on the promotional ladder. For reference, railway clerks worked indoors and did not need strength to perform their duties. This grade had an average annual fatal accident risk rate of less than 1 fatality per 10,000 employed over the period 1896-1913. In the same period, the porter grade had a fatal accident risk rate of 10.4 per 10,000 employed whereas signalmen faced a risk of 3.3 deaths per 10,000.

The same held true for shunters and goods guards, two of the most dangerous grades in railway work. Shunters had an annual average risk of fatal injury of 29 per 10,000 employed over these 18 years. Goods guards, because they still performed shunting tasks, suffered an annual average of $\mathbf{2 4 . 5}$ deaths. Whilst high, it indicates the lower physical exertion and danger that came with a promotion from shunter to goods guard.

The second matter relates to the irreplaceable skills of signalmen and goods guards. Unlike the entry-level grades from which these men ascended, a man offering only his physical prowess could not perform these duties. Contemporary reports counted goods guards and signalmen amongst the grades with idiosyncratic skills that companies could not seamlessly replace (PP 1911, [Cd. 5927]),especially in the event of a strike (NA, HO 45/10655/212470), and companies rarely filled these higher-level grades with an external candidate, if ever (NA, RAIL 1025/21).

\section{The data set}

The data set consists of a sample of 2206 railwaymen taken from the staff books of the London and North-Western (1703), London and South-Western (320), and Great Western (183), all held at the National Archives at Kew. The ledgers record men who entered railway service in one of these companies operating and traffic departments sometime between 1861 and 1926 . Evidence from the earliest years is sparse and this study ends at the advent of the First World War. The ledgers did not include platelayers and locomotive department railwaymen while my selection process purposely excluded salaried workers, such as station masters, and entrants below the age of 18 so as to only record terminal heights.

At a minimum, each ledger provided a man's name, date of birth, date of entry into service, current station and date begun there, current grade, current weekly wage, and his terminal height. Each data point is a railwayman observed at some point from 1874-1913. The majority of these men worked as a porter, shunter, signalman, or goods guard (brakesman) while the remaining worked in other wage-paying grades such as gatemen or inspectors. The ledgers did not differentiate between passenger and goods porters and in some instances they merely classified a man as a guard, making it possible that the goods guards in the data set contain some passenger guards.

It is unknown why all three companies entered some men's height and not others, possibly recording them unsystematically. They also kept records in different ways. The London and North-Western ledgers give the details of the men that filled the particular grades at a particular station. When a man left this position, the clerk crossed him off and input the details of the man replacing him. The London and South-Western and Great Western provide staff histories of an individual from the time he entered the company to his exit, the latter company's ledger pertaining to men stationed in Wales.

A randomly generated number determined the frequency with which an entry was selected from the London and North-Western and the London and South-Western's ledgers. All of the Great Western men with a recorded height were selected in an attempt to better represent Wales-based railwaymen. Because these latter two companies' ledgers are staff histories, a randomly generated number determined which year of a man's history was recorded. The random selection of a year in a man's history sought to avoid introducing bias into the selected tenure. The same was done to avoid selection bias amongst the London and North-Western grades.

It is difficult to test the sample data against known characteristics of the railway industry because of the paucity of similar data. Table 1 compares the average nominal weekly wages from the data set with the average nominal earnings, which included bonuses 
Table 1

Average weekly wage and earnings comparison, 1896-1912.

\begin{tabular}{lllll}
\hline Year & England \& wales & Data set & Data set observations & Difference (wages - earnings) \\
\hline 1896 & 24.42 & 25.44 & 43 & 1.02 \\
1897 & 24.88 & 27.73 & 121 & $2.85^{* * *}$ \\
1898 & 25.12 & 27.73 & 119 & $2.61^{* * *}$ \\
1899 & 25.81 & 26.21 & 94 & 0.40 \\
1900 & 25.58 & 28.00 & 109 & $2.42^{* * *}$ \\
1901 & 25.52 & 26.75 & 88 & $1.23^{* *}$ \\
1902 & 25.44 & 25.21 & 119 & -0.23 \\
1903 & 25.38 & 24.95 & 106 & -0.43 \\
1904 & 25.58 & 25.17 & 78 & -0.41 \\
1905 & 25.85 & 25.52 & 74 & -0.33 \\
1906 & 25.96 & 26.47 & 114 & 0.51 \\
1907 & 26.40 & 25.36 & 151 & $-1.04^{* *}$ \\
1908 & 25.52 & 26.59 & 105 & $1.07^{*}$ \\
1909 & 25.58 & 25.34 & 89 & -0.24 \\
1910 & 26.29 & 25.49 & 129 & -0.80 \\
1911 & 27.35 & 24.50 & 100 & $-2.85^{* * *}$ \\
1912 & 28.00 & 25.12 & 12 & $-2.88^{* *}$ \\
\hline
\end{tabular}

Source: Parliamentary Papers, 'Report on changes in rates of wages' years 1897-1913. See text for data set's source.

Note: monetary values in shillings.

* Difference significant at the $10 \%$ level.

** Difference significant at the $5 \%$ level.

*** Difference significant at the $1 \%$ level.

and overtime pay, of all English and Welsh railwaymen from 1896-1912. A two-tailed $t$-test of the differences in means shows that for 10 of the years there is no statistical difference in the averages at a $5 \%$ significance level. The workings of the Conciliationand Arbitration Scheme after the August 1911 railway strike likely caused the higher earnings in the final two years. This close proximity between wages and earnings suggests that the data set is reflective of higher-waged workers in railway operating and traffic departments.

A like-to-like comparison is the average nominal weekly wage of railwaymen in operating and traffic departments. This datum for the United Kingdom in 1907 is $24.4 \mathrm{~S}$ (PP 1912-13, [Cd. 6053]), a difference of less than a shilling compared to the same year in Table 1, a difference likely wholly attributable to the inclusion of lower-paid Irish and Scottish railwaymen in the Board of Trade's figure. In 1911, railwaymen working in these grades for the 10 largest English and Welsh railway employers earned an average weekly wage of 24.15 s (PP 1913, (116)) a number that compares favourably with the data set's figure in Table 1.

Ideally, there would be an explanation as to why these companies listed some men's height and not others in addition to more recorded heights of railwaymen. To better determine industry-wide applicability would necessitate the Board of Trade having required companies to supply average weekly wage rates. Nevertheless, in light of available evidence, it does seem that at a minimum, the data set is a reasonable representation of English and Welsh railwaymen working in operating and traffic departments.

\section{Analysis of the data}

An OLS regression is used to determine the effect of height on railwaymen's wages. In addition to the height of each individual railwayman, the sample also includes his age, tenure, grade, company, location of his station, and the year he worked there. Table 2 provides the averages of the variables with the standard deviation in parentheses for all railwaymen and four selected grades.

The dependent variable is the natural log of real weekly wages in shillings, for a railwayman working in grade $i$ for company $j$ at a station located in a city with population $r$ in entry cohort $z$ in time $t$. The wages were deflated by Feinstein's CPI, which used 1904 as the base period (1972). The model is similar to Eichengreen and Gemery's (1986) estimation of the weekly earnings of American immigrants and takes the form:

\footnotetext{
lnrwage $_{\text {ijrzt }}=\beta_{0}+\beta_{1}$ age $_{\text {ijrzt }}+\beta_{2}$ age $2_{\text {ijrzt }}+\beta_{3}$ tenure $_{\text {ijrzt }}+\beta_{4}$ tenure $2_{\text {ijrzt }}+\beta_{5}$ height $_{\text {ijrzt }}+$ $\beta_{6} \mathrm{GRADE}+\beta_{7} \mathrm{COMPANY}+\beta_{8} \mathrm{CITY}+\beta_{9} \mathrm{SLOWDOWN}+\beta_{10} \mathrm{YEAR}+\mathrm{e}_{\mathrm{ijrzt}}$
}

Railwaymen would have likely received positive returns to age and tenure, as on-the-job training increased their skill (Joby, 1984). The quadratic age and tenure variables take into account that returns to these characteristics should diminish as the physical capacities of railwaymen, such as eyesight (PP 1912-13, [Cd. 6014]) or reflexes, deteriorated with age. For reasons stated above, height should positively affect railwaymen's wages, although this test will not determine the underlying cause of the premium.

The GRADE variable is a vector of dummy variables accounting for the grade in which the man worked, including those that had a position of authority within a grade, such as a head shunter. The COMPANY vector controls for the railway company of employ and CITY is a vector dummy breaking down the population of the city in which the railwayman worked into 6 categories (Mitchell, 1962). SLOWDOWN controls for those entering the industry after 1899, as the turn-of-the-century slowdown in the railway industry's growth and subsequent slower growth of better-paying jobs may have stymied abler men in this cohort from ascending to the better positionsthey would have attained in an earlier time. It also controls for slow-growing industry demand not offsetting the growing supply of 
Table 2

Summary statistics.

\begin{tabular}{|c|c|c|c|c|c|c|}
\hline Variable & Definition & All grades & Porters & Shunters & Signalmen & Guards \\
\hline lnrwage & Natural log of weekly real wage (shillings) & $3.29(0.220)$ & $3.01(0.137)$ & $3.29(0.153)$ & $3.34(0.149)$ & $3.47(0.147)$ \\
\hline rwage & Weekly real wage (shillings) & $27.55(6.00)$ & $20.56(2.95)$ & $27.33(4.12)$ & $28.57(4.17)$ & $32.47(4.92)$ \\
\hline age & Individual's age in observed year & $34.90(9.86)$ & $28.72(8.35)$ & $31.53(7.83)$ & $37.44(9.51)$ & 38.54 (9.09) \\
\hline age2 & Quadratic of age & & & & & \\
\hline tenure & Individual's tenure in observed year & $11.68(9.45)$ & $5.44(7.27)$ & $8.31(7.89)$ & $14.21(9.07)$ & $15.70(8.70)$ \\
\hline tenure 2 & Quadratic of tenure & & & & & \\
\hline height & Railwayman's height (inches) & $68.05(1.78)$ & $68.19(1.74)$ & $67.80(1.91)$ & $68.05(1.64)$ & $68.08(1.91)$ \\
\hline GRADE & Dummy variables controlling for grade & & & & & \\
\hline COMPANY & $\begin{array}{l}\text { Dummy variables controlling for railway } \\
\text { company employer }\end{array}$ & & & & & \\
\hline CITY & $\begin{array}{l}\text { Dummy variable controlling for population } \\
\text { of city station }\end{array}$ & & & & & \\
\hline SLOWDOWN & $\begin{array}{l}\text { Dummy variable controlling for slowing } \\
\text { industry growth after } 1899\end{array}$ & & & & & \\
\hline YEAR & Dummy variable controlling for year & & & & & \\
\hline Observations: & & 2206 & 426 & 354 & 776 & 496 \\
\hline
\end{tabular}

Source: See text.

Table 3

OLS estimates of determinants of railwaymen's wages.

\begin{tabular}{|c|c|c|c|c|c|}
\hline & \multicolumn{5}{|c|}{ Natural log of real weekly wages } \\
\hline & All grades & Porters & Shunters & Signalmen & Guards \\
\hline AGE & $0.016^{* * *}(0.002)$ & $-0.001(0.005)$ & $0.009(0.006)$ & $0.026^{* * *}(0.004)$ & $0.027^{* * *}(0.007)$ \\
\hline AGE2 & $-0.0002^{* * *}(0.00003)$ & $0.00003(0.00008)$ & -0.0001 (0.00009) & $-0.0003^{* * *}(0.00006)$ & $-0.0003^{* * *}(0.00009)$ \\
\hline TENURE & $0.011^{* * *}(0.001)$ & $0.018^{* * *}(0.003)$ & $0.007^{* * *}(0.002)$ & $0.009^{* * *}(0.002)$ & $0.014^{* * *}(0.004)$ \\
\hline TENURE2 & $-0.00009^{* *}(0.00004)$ & $-0.0005^{* * *}(0.0001)$ & $-0.0001(0.0001)$ & $-0.00002(0.00006)$ & $-0.0001(0.0001)$ \\
\hline HEIGHT & $0.005^{* * *}(0.001)$ & $0.001(0.002)$ & $-0.003(0.002)$ & $0.008^{* * *}(0.002)$ & $0.009^{* * *}(0.002)$ \\
\hline CONSTANT & $2.483^{* * *}(0.094)$ & $2.893^{* * *}(0.204)$ & $3.154^{* * *}(0.192)$ & $1.973^{* * *}(0.170)$ & $1.936^{* * *}(0.226)$ \\
\hline R-Squared & 0.799 & 0.590 & 0.783 & 0.604 & 0.585 \\
\hline Observations & 2206 & 426 & 354 & 776 & 496 \\
\hline
\end{tabular}

Source: See text.

${ }^{*}$ Significant at the $10 \%$ level.

** Significant at the $5 \%$ level.

*** Significant at the $1 \%$ level.

literate workers and the suppression in the return to literacy this may have caused. The YEAR vector is a full set of year dummies, 1874-1913, and controls for factors like the Conciliation and Arbitration Schemes. The reference category is Great Western signalmen stationed in a city with a population of fewer than 18,000 people in the year 1904 and who entered the industry after 1899. Table 3 shows the regression's results.

The explanatory variables in this regression account for nearly $80 \%$ of the variation in railwaymen's weekly wages. The age and tenure variables, as predicted, both positively affect a man's wage subject to diminishing returns. The tenure coefficients show that the return to an extra year of tenure ceased at 60 years of experience, which has little practical importance as age and mandatory retirement schemes ended railway careers before such an advanced age (NA, RAIL 264/11).

The coefficient on height, for all railwaymen, is positive and statistically significant at a level below $0.1 \%{ }^{3}$ The variable indicates that a railwayman 1 inch taller than his co-worker received a $0.5 \%$ higher weekly real wage, holding other factors constant. In monetary terms, consider the example of a London and North-Western signalman in 1905, stationed in a city the size of Liverpool or Birmingham, and having entered the industry before 1900. Evaluated at the data set's mean age, tenure, and height, a signalman one standard deviation taller than the average would have earned 3.39d more per week, in real terms, than his shorter counterpart. This translates to $14.40 \mathrm{~s}$ more over a 51-week work year (NA, RAIL 1025/21).

Such a difference was not trivial at a time when a pint of beer cost 2d at a London pub (Hicks and Allen, 1999). The taller man's wage premium would have made it possible for him to afford an extra $7 \mathrm{lbs}$ of potatoes per week or an extra quart of milk per week in Birmingham, Liverpool, or Manchester. Every month this taller railwayman could have purchased a dozen more eggs in Liverpool or Manchester (PP 1908, [Cd. 3864]).

\footnotetext{
${ }^{3}$ The same model with a quadratic height variable results in neither height variable statistically significant at conventional levels, a result at odds with the evidence of companies' minimum height standards at entry and promotion.
} 


\subsection{The wage-height premium by railway grade}

It would be premature to infer from Table 2 that the wage-height premium was due to greater strength just because porters had a taller mean height than signalmen. The data set is comprised of a random sample of railwaymen irrespective of their age or promotion to another grade at a later date. Some entries are of relatively taller men working in entry-level grades who eventually received a promotion to a grade that required greater intelligence. For instance, a London and North-Western railwayman with the surname Hannah had a height of 69 inches and is recorded in the data set as a head shunter, but he eventually became a station master.

To tease out the source of the wage-height premium, the same regression as above was run separately for four subsets within the data, porters, signalmen, shunters, and goods guards. The GRADE vector is excluded except for the variable that controls for a superior in that grade. Table 3 reports the results.

In these separate regressions, age benefited signalmen and goods guards' wages, again at a diminishing rate, but not those of porters and shunters. This is indicative of the age-associated abilities needed to perform skilled railway work, but not unskilled work. With maturity comes a willingness to undertake responsibility, the ability to physically and mentally react to changing situations, diligence, and reflexes. It also means that the variable age controls for some age-specific physical abilities. Signalmen and goods guards needed these abilities to perform their tasks and ensure safety, but like eyesight, some of these faculties faded with the advancement of time. Hence the positive return to age ceased for signalmen and guards at 36 and 41 years of age, respectively.

Tenure is statistically significant and positively correlated to wages for all four subsets of railwaymen. This captures railwaymen's accumulation of specific-human capital during their tenures, which companies rewarded by commonly tying increases in pay to tenure. This explains railwaymen's long tenures, as the accumulation of company-specific skill gave both companies and railwaymen the incentive to sustain the working relationship. Statistically, the return to tenure ceased at around 16 years for porters, but not the other three grades, as companies demoted older railwaymen or those who failed eyesight tests to the porter grade but not the other three. Increased tenure, then, would not have benefited the men demoted from higher grades.

Unlike tenure, the coefficient on height is only positive and statistically significant, below the $0.1 \%$ level, for the skilled grades, goods guard and signalman. Aspirants to the signalman grade, porters, had an economically small and statistically insignificant variable on height even though their work required more physical labour than signalmen. Some misestimation may stem from the inability to distinguish between passenger and goods porters; however, all porters needed a greater strength to intelligence ratio for their duties than signalmen. That height only received a reward in the skilled grade suggests the former represents cognitive and noncognitive ability, not a man's strength.

The same holds true in the job ladder containing shunters and goods guards. The coefficient on height for shunters had a negative sign and is statistically insignificant despite shunters needing the highest ratio of physical to mental skill of these four grades. It is thus nonsensical that height, if it was a proxy for strength, would have received a premium in the goods guard grade, but not in the shunting grade, as these grades shared some physical tasks. The wage-height premium in the goods guard grade then likely accounts for the greater cognitive and or non-cognitive skills men needed for success in this grade.

A case can also be made against a railwaymen's height representing his health. Railway companies wanted healthier men in every grade, making it implausible that they would only reward this in higher-level grades. Additionally, the infirm and unfit would have been weeded out at the beginning of their railway service making it conceivable that all signalmen and goods guards were relatively sturdy, healthy individuals. Height then would not correlate to health because there would be little variation of the latter in higher-level grades. Railwaymen's sick records would make it possible to test this point, but such data is not available, if it ever existed.

Another test supports these conclusions. Railwaymen higher up the promotional ladder should have had greater mean heights, but the selection method for the data set negated the validity of such comparisons within the sample. The mean height of station masters, however, corroborates that cognitive and or non-cognitive ability was the reason for the wage-height premium.

Companies drew some station masters from their clerks while others entered railway work on the lowest rung of a waged job ladder (PP 1911, [Cd. 5927]). The available evidence on the height of station masters in the surviving railway staff books is scarce, but this paper uses a random sample of 186 London and North-Western station masters culled from the same London and North-Western staff ledgers used for the data set. Over $88 \%$ of these men were born before 1870 , biasing the sample towards an earlier, likely shorter, birth cohort.

The station masters had a mean height of 68.86 inches while the railwaymen in the data set had an average height of 68.05 inches, paralleling the modern average height of South Korean and Moroccan adult males, respectively (www.averageheight.co). A difference in means tests shows that this disparity is statistically significant at the $0.1 \%$ level. The difference in the mean height of the London and North-Western station masters with the mean height of the London and North-Western railwaymen in the data set is 0.82 inches, a difference also statistically significant at the $0.1 \%$ level.

\subsection{Missing variables}

A variable accounting for each railwayman's human capital is the most important missing variable in these tests. If cognitive ability caused the wage-height premium in the railway industry then the estimates of the height coefficients are biased. The inclusion of a variable recording each railwayman's literacy skills or results in signalman school, for instance, would cause a noticeable drop in the coefficient on height, which might also become statistically insignificant.

Alternatively, non-cognitive ability, which positively impacts labour market performance and opportunities (Bowles et al., 2001; Heckman et al., 2006; Humphries and Leunig, 2009) and is strongly correlated to cognitive ability, may drive this wage-height 
premium. These skills are not easily quantifiable and it is difficult to think of such a measure that might have been recorded for these railwaymen. Bear in mind, though, that personal discipline and the ability to work with others are non-cognitive skills. Like the above discussion on health, it is plausible that railwaymen lacking these qualities would have exited the industry early in their tenures, giving little variability to these qualities in skilled grades. However, poor screening processes at promotion might make for sizable variance in health and non-cognitive skills in higher grades.

Inclusion of hypothetical variables to control for railwaymen's cognitive and non-cognitive skills and health may show incorrect the whole of the previous arguments. Perhaps heightism was alive and well in the British railway industry of this time and taller men received higher paying jobs simply because of their superiors' predilection for the tall. While in part addressed below, this seems unlikely as the companies' incentive to achieve efficiency and safety in railway operations should have outweighed any latent heightism.

Unfortunately, these missing variables do not exist in the staff ledgers that recorded railwaymen's height. Some broader historical educational variables exist, such as Matthews et al. (1982), which gives the average number of years of schooling for English and Welsh males. The figures are decadal, however, making them a blunt variable, at best, in a model that includes a number of measures specific to each railwayman.

\section{Signalmen: discipline and height}

One way to test for the existence of heightism is through the relationship between height and discipline. If taller railwaymen were favoured by their superiors simply for being tall, then taller men should have had a lower probability of receiving a fine after committing an infraction. Punishment on the railways came in the form of fines, cautions, pay decreases, suspension, demotions, and dismissal (Savage, 1998). Railwaymen also received positive enforcement for good behaviour (Kingsford, 1970) in the form of bonuses which they could lose for committing an infraction 4 (NA, RAIL 1025/21). Within this system of reward and discipline, taller men appear not to have had an advantage.

The data is drawn from the same Great Western railwaymen recorded in the data set. Only this ledger recorded a man's disciplinary history and height. The focus is on signalmen because their errors, particularly those causing harm to people or equipment, could not easily escape a superintendent's detection, which minimises selection bias. Of the 183 Great Western railwaymen in the data set, 60 committed at least one infraction as a signalman. This is the total population of reprimanded Great Western signalmen stationed in Wales with a recorded adult height, albeit a tiny population.

A probit model is used to estimate the relationship between height and receiving a monetary fine. Sometimes the man's punishment was a deferred bonus, although it is not clear if this meant delayed payment or a permanent deferment (NA, RAIL 1025/21). In either case, these deferments qualify as a monetary discipline because even in the case of a postponement the present value of the sum exceeded its future value. The probit regression considers a man's first recorded infraction as a signalman and assigns a 1 to those that received a monetary fine and a o to those who did not. Considering their first infraction eliminates any stickiness inherent in railway officials' determination of the penalty for later infractions. The model takes the form:

$$
\text { fine }_{\mathrm{rs}}=\beta_{0}+\beta_{1} \text { height }_{\mathrm{rs}}+\beta_{2} \text { tenure }_{\mathrm{rs}}+\beta_{3} \text { disciplined }_{\mathrm{rs}}+\beta_{4} \mathrm{CITY}+\beta_{5} \text { INFRACTION }+\mathrm{e}_{\mathrm{rs}}
$$

The dependent variable, fine, is for a railwayman working at a station with population $r$ and who broke a rule of severity $s$. Height gives the man's terminal height and tenure is the number of years he had worked at the time of his infraction. Disciplined is the number of times the man had already been disciplined as a proportion of his tenure. Contemporary accounts stressed the positive impact that a clean record could have on a railwayman's career (Railway Times, 1911; Reynolds, 1881) and only three men in this data set had a recorded infraction prior to becoming a signalman.

Two qualitative variables, CITY and INFRACTION, are also included. The former is to control for men stationed in Cardiff, Newport, or elsewhere. INFRACTION provides dummies to qualify for the severity of the signalman's misdeed. It considers causing a collision, derailment, delay, or some miscellaneous breaking of the rules such as the use of 'impertinent language'. The reference category is a man working at a station not in Cardiff or Newport and who caused some form of collision. Table 4 shows the probit regression's results with standard errors in parentheses.

The overall model is statistically significant at the $0.1 \%$ level, but only two coefficients from the INFRACTION vector are statistically significant at conventional levels. It seems then that taller Great Western signalmen enjoyed no advantage in avoiding monetary fines. Perhaps this outcome is a consequence of the small sample size, but there was also no statistical difference between the height of signalmen in the ledger who received a fine and those who did not. The 18 signalmen in this ledger that did not have a recorded infraction in their respective histories had an average height of 67.63 inches, less than 0.06 inches shorter than the average height of the 60 signalmen with a recorded infraction, a difference that is not statistically significant at conventional levels. It is impossible to know if these 18 men were caught breaking rules, but not reported, as the ledger makes no mention of such incidents. If this did happen, the leniency they received was not due to them being markedly taller.

These findings are consistent with improving passenger safety during this time period. The number of passengers that died as a result of train accidents not caused by failure of equipment or the permanent way quantifies human error, such as incorrect signalling, because passenger safety was at the mercy of railwaymen's actions. From $1896-1912,{ }^{5}$ slightly more than 13 passengers died per

\footnotetext{
4 The value of a Great Western signalman's monthly bonus was $8 \mathrm{~s} 4 \mathrm{~d}$. (GWR, RAIL 1025/21).

5 Casualties - The Board of Trade standardised the definition of non-fatal injuries to railwaymen and passengers in 1896 amidst rumours that companies underreported both fatal and non-fatal injuries (Bagwell, 1963). Train Miles - 1912 is the last year companies reported total train miles run.
} 
Table 4

Probit estimates of taller signalmen's likelihood of receiv-

ing a fine upon first infraction.

\begin{tabular}{ll}
\hline & Signalmen \\
\hline HEIGHT & $-0.251(0.153)$ \\
TENURE & $0.079(0.065)$ \\
DISCIPLINED & $0.245(3.029)$ \\
CONSTANT & $17.05(10.54)$ \\
Observations & 60 \\
Prob > chi2 & 0.001 \\
Pseudo R2 & 0.3274 \\
\hline
\end{tabular}

Source: see text.

${ }^{*}$ Significant at the $10 \%$ level.

${ }^{* *}$ Significant at the $5 \%$ level.

*** Significant at the $1 \%$ level.

year in England and Wales on average, excluding those fatalities on the Great Western, this during a time of increasing passenger miles run. On average, 0.48 passengers died per year every 10 million train miles run. The Great Western averaged less than one passenger fatality per year and lost 0.12 passengers per year for every 10 million train miles run, over the same period ( $P P$ 1896-1913, Accidents).

The evidence of improving passenger safety on the railways is consistent with the companies' incentive to promote their best and brightest to ensure safety and not to promote or favour men based solely on their height. In this way, the passenger fatality data supports Table 4's evidence against heightism, a conclusion consistent with this paper's earlier evidence.

\section{Interpreting the cognitive and non-cognitive conclusions}

These conclusions may seem counterintuitive in light of the physical nature of many Victorian and Edwardian jobs, but they should not be for this very reason. This was a time when intelligence and non-cognitive ability remained scarce relative to men who had only their strength to offer an employer. Unskilled labour exceeded demand in York (Rowntree and Lasker, 1911) and the Midland Railway received 6 applications per open position in their goods and coaching departments (PP 1911, [Cd. 5927]). From 1870-1913, the unemployment rate for unskilled British workers was almost $80 \%$ higher than for semiskilled and skilled workers (Boyer and Hatton, 2002). Under these labour market conditions, employers would not have needed to pay a premium to attract men that could only perform physical work because their supply was already in surplus. This explains why height, as a proxy of cognitive and noncognitive skills, earned no premium in unskilled, entry-level railway grades, but did so in the skilled grades.

A final potential objection to these findings is that railway companies did not know of the link between height and cognitive and non-cognitive ability. However, railway companies looked for healthy, robust individuals at both the point of entry and when screening for promotion. That would explain why, for example, promotion in the Great Western in part hinged on the quality of a man's teeth, which would have directly affected his health. Thus it is likely that railway companies wanted tall and healthy looking men because they understood this indicated the man could work harder and would prove less susceptible to illness. Inadvertently, then, the railway companies hired men with better cognitive and non-cognitive abilities who would eventually move up the railway job ladder where their intelligence and non-cognitive skills, represented by height, earned a higher return.

\section{Conclusion}

This paper's research has produced several interesting results. Based on a new data set of British railwaymen, it first showed that a wage-height premium existed in the late Victorian and early Edwardian railway operating and traffic departments. The paper further tested what caused the premium on height. Entry-level railway grades relied primarily on physical strength whereas higherlevel grades necessitated a greater use of cognitive and non-cognitive abilities. By looking at the effect of height on the wages of two entry-level grades and two higher level grades, it was found that taller men working in the entry-level grades of porter and shunter did not receive a premium in their wages. In contrast, taller men in the grades to which porters and shunters could receive a promotion, signalman and goods guard, respectively, received a wage premium, controlling for other factors. This indicated that taller railwaymen received a wage premium due to relatively higher intelligence and or non-cognitive ability, not physical strength. Furthermore, separate evidence on the height of station masters, a final destination on the career ladder, showed that they had a statistically significant greater average height than railwayman in the data set.

The relationship between height and discipline did not indicate preferential treatment for taller men. Using a data set of 60 Great Western signalmen stationed in Wales, it was found that taller men did not have a statistically significant lower probability of receiving a monetary punishment for committing an infraction. These results should be subject to caution, but the evidence comes from a time of improving railway safety, which also contradicts the contention that favouritism for the tall explains the wage-height premium.

Such findings may prove of wider interest for the British labour market during this period, particularly if heretofore unidentified information on the height of railwaymen is added to this work. British railway companies were the largest employers at this time, 
making the extent to which they bid on labour in a competitive labour market indicative of the extent to which these findings apply to the whole of the British labour force.

\section{Supplementary materials}

Supplementary material associated with this article can be found, in the online version, at doi:10.1016/j.eeh.2017.12.001.

\section{References}

Alderman, G., 1971. The railway companies and the growth of trade unionism in the late nineteenth and early twentieth centuries. Hist. J. 14 (1), 129-152. Bagwell, P.S., 1963. The Railwaymen: The History of the National Union of Railwaymen. George Allen and Unwin, London.

Bowles, S., Gintis, H., Osborne, M., 2001. The determinants of earnings: a behavioral approach. J. Econ. Lit. 39 (4), 1137-1176.

Boyer, G.R., Hatton, T.J., 2002. New estimates of british unemployment, 1870-1913. J. Econ. Hist. 62 (3), $643-675$.

Bozzoli, C., Deaton, A., Quintana-Domeque, 2009. Adult height and childhood disease. Demography 46 (4), 647-669.

Case, A., Paxon, C., 2008a. Height, health, and cognitive function at older ages. Am. Econ. Rev. 98 (2), 463-467.

Case, A., Paxon, C., 2008b. Stature and status: height, ability, and labor market outcomes. J. Political Economy 116 (3), $499-532$.

Crafts, N., Leunig, T., Mulatu, A., 2011. Corrigendum: were British railway companies well managed in the early twentieth century? Econ. Hist. Rev. 64 (1), $351-356$. Croppenstedt, A., Muller, C., 200o. The impact of farmers' health and nutritional status on their productivity and efficiency: evidence from ethiopia. Econ. Dev. Cultural

Change 48 (3), 475-502.

Discipline and Seniority in Railway Service, 1911. The railway times (11 Nov. 1911), 469.

Doeringer, P.B., Piore, M.J., 1985. Internal Labor Markets and Manpower Analysis. M. E. Sharpe, Inc, Armonk.

Eichengreen, B., Gemery, H.A., 1986. The earnings of skilled and unskilled immigrants. J. Econ. Hist. 46 (2), $441-454$.

Feinstein, C.H., 1972. National Income, Expenditure and Output of the United Kingdom. Cambridge University Press, Cambridge, pp. $1855-1965$.

Floud, R., Watchter, K., Gregory, A., 1990. Height, Health and History. Cambridge University Press, Cambridge.

Gospel, H.F., 1992. Markets, Firms, and the Management of Labour in Modern Britain. Cambridge University Press, Cambridge.

Heckman, J., Stixrud, J., Urzua, S., 2006. The effects of cognitive and noncognitive abilities on labor market outcomes and social behavior. J. Labor Econ. 24 (3), $411-482$.

Howlett, P., 200o. Evidence of the existence of an internal labour market in the great eastern railway company, 1875-1905. Bus. Hist. 42 (1), 21-40.

Howlett, P., 2004. The internal labor dynamics of the great eastern railway company, 1870-1913. Econ. Hist. Rev. 57 (2), $396-422$.

Humphries, J., Leunig, T., 2009. Was dick whittington taller than those he left behind? anthropometric measures, migration and the quality of life in early nineteenth century London. Explor. Econ. Hist. 46 (4), 120-131.

Joby, R.S., 1984. The Railwaymen. David and Charles London.

Kenney, R., 1913. Men and Rails London.

Kenney, R., 1939. Westerling: An Autobiography. J.M. Dent and Sons Ltd, London.

Kingsford, P.W., 1970. Victorian Railwaymen: The Emergence and Growth of Railway Labour. Cass, London, pp. 1830-1870.

Komlos, J., 1990. Height and social status in eighteenth-century Germany. J. Interdiscip. Hist. 20 (4), 607-621.

Rowntree, B.S., Lasker, B., 1911. Unemployment, A Social Study. Macmillan and Co., Ltd, London.

Lunborg, P., Nystedt, P., Rooth, Dd-O., 2014. Height and earnings: the role of cognitive and noncognitive skills. J. Human Resour. 49 (1), $141-166$.

Margo, R.A., Steckel, R.H., 1982. The height of American slaves. Soc. Sci. Hist. 6 (4), 516-538.

Matthews, R.C.O., Feinstein, C.H., Odling-Smee, J., 1982. British Economic Growth 1856-1973: The Post-War Period in Historical Perspective. Stanford University Press, Stanford.

Mitchell, B.R., 1962. Abstract of British Historical Statistics. Cambridge University Press, Cambridge.

Palloni, A., 2006. Reproducing inequalities: luck, wallets, and the enduring effects of childhood health. Demography 43 (4), 587-615.

Reynolds, M., 1881. Engine-Driving Life or Stirring Adventures and Incidents in the Lives of Locomotive Engine-Drivers. Crosby Lockwood \& Co.,London, London.

Savage, M., Discipline, 1998. Surveillance and the "career": employment on the great western railway 1833-1914. In: McKinlay, A., Starkey, K. (Eds.), Foucault, Management and Organization Theory. Sage Publications, London, pp. 65-92.

Schick, A., Steckel, R.H., 2015. Height, human capital, and earnings: the contributions of cognitive and noncognitive ability. J. Human Capital 9 (1), 94-115.

Schmidt, F.L., 2002. The role of general cognitive ability and job performance: why there cannot be a debate. Human Perform. 15 (1/2), 187-210.

Schofield, R.S., 1973. Dimensions of literacy: 1750-1850. Explor. Econ. Hist. 10 (4), 437-454.

Simmons, H.A., 1974. Ernest Struggles; Or the Comic Incidents and Anxious Moments in Connection with The Life of a Station Master. Market Place, Reading, By One Who Endured It. J.J. Beecroft.

Thomas, D., Strauss, J., 1997. Health and wages: evidence on men and women in Urban Brazil. J. Econometrics 77 (1), $159-186$.

Wardley, P., 1991. The anatomy of big business: aspects of corporate development in the twentieth century. Bus. Hist. 33 (2), $268-296$.

Wardley, P., 1999. The emergence of big business: the largest corporate employers of labour in the United Kingdom, Germany and the United States c. 1907. Bus. Hist. 41 (4), 88-116.

Westwater, T.A., 1979. The Early Life of T.A. Westwater: Railway Signalman. Trade Unionist and Town Councillor in County Durham, Ruskin College Library, Oxford.

\section{National archives at kew}

Great Eastern Railway - Wages and hours arbitration: Minutes of proceedings and award, 1909, (RAIL 1025/10).

Great Western Railway - Memorandum Book No. 2, 1900-32, (RAIL 264/10).

Great Western Railway -Memorandum Book No. 3, 1903-08, (RAIL 264/11).

Great Western Railway - Wages and hours arbitration: Vol. 1 award and minutes of proceedings, (RAIL 1025/21).

Home Office -Strikes: Liverpool Railway Strike 1911, (HO 45/10655/212470).

North British Railway -Conciliation Board No. 1 (Signalmen): Report of Proceedings at Arbitration, 1912, (BR/LAS/S/105).

North British Railway - Wages and hours arbitration: minutes of proceedings and award, 1909, (RAIL 1025/18).

North Eastern Railway - Men entitled to extra pay for services during the Newcastle Strike, 1900, and a memo re minimum height of firemen (NER), 1901, (RAIL $527 / 1258)$.

\section{National Archives at Kew, Data Set}

London and North Western Railway - Register of salaried and waged staff, 1903 - 1910, (RAIL 410/1804).

\section{National records of Scotland}

North British Railway - Conditions of Service, Rates of Pay, Numbers of Staff, etc., 1907 (BR/LAS/S/49). 


\section{On-line references}

Average Height for a Man. http://www.averageheight.co/average-male-height-by-country.

Dickens, C., 1866. The Signal-Man. http://www.eastoftheweb.com/short-stories/UBooks/BranLine.shtml.

Hicks, J., Allen, Grahame, 1999. A Century of Change: Trends in UK Statistics Since 1900. House of Commons Library Research Paper 99/111,

http://researchbriefings.parliament.uk/ResearchBriefing/Summary/RP99-111.

\section{Parliamentary references}

Parliamentary Papers 1896-1913, Railway accidents. Return of accidents, annual reports.

Parliamentary Papers 1881-1913, Returns of the Capital, Traffic, Receipts, and Working Expenditure.

Parliamentary Papers 1897-1913, Report on changes in rates of wages, annual reports.

Parliamentary Papers 1908, cvii [Cd. 3864], Cost of living of the working classes: United Kingdom.

Parliamentary Papers 1911, xxix [Cd. 5927], Railways: agreements and amalgamations.

Parliamentary Papers 1912-13, xlv [Cd. 6014], Railways: Royal Commission: Railway Conciliation Scheme, 1907 (Strike of 1911).

Parliamentary Papers 1912-13, cviii [Cd. 6053], Enquiry into earnings and hours of labour.

Parliamentary Papers 1913, lviii (116), Salaries and wages of railway staff. 